Семенов А. О., кандидат фізико-математичних наук, Кожушко Г. М., доктор технічних наук, Сахно Т. В., доктор хімічних наук

Полтавський університет економіки і торгівлі

\title{
ВПЛИВ ПЕРЕДПОСАДКОВОГО УФ-ОПРОМІНЕННЯ НА РОЗВИТОК І ПРОДУКТИВНІСТЬ КАРТОПЛІ
}

\section{Рецензент - доктор сільськогосподарських наук, завідувач кафедри товарознавства продовольчих товарів $Г$. О. Бірта}

В роботі досліджено вплив ультрафіолетового (УФ) опромінення на клубні картоплі перед садінням. Експериментальні дослідження проводилися на середньоранніх сортах картоплі «Утро ранее» та «Рокко» $з$ використанням ультрафіолетових ртутних розрядних ламп низького тиску. Встановлено, щуо у рослин, які перед садінням були опромінені дозою 120-240 Дю/ ${ }^{2}$, прискорено утворювалися і розвивалися первинні коріння. Крім того, у рослин посилюється вететативний ріст та збільшується врожайHicmb.

Ключові слова: УФ-опромінення, доза опромінення, передпосадкова обробка, продуктивність картоплі, процеси розвитку.

Постановка проблеми. Оптичне випромінювання широко використовується в агропромисловому комплексі для розробки нових технологій, спрямованих на підвищення продуктивності рослинної продукції. Одним із напрямів використання оптичного випромінення $\epsilon$ передпосівна обробка насіння сільськогосподарських культур ультрафіолетовим випроміненням.

Дослідження впливу передпосівного опромінення насіння рослин ультрафіолетовим випроміненням на їх розвиток, продуктивність, зараження грибковими та іншими захворюваннями розпочато відносно недавно і ця проблема вивчена ще не досить грунтовно, тому дослідження в даному напрямку є актуальними.

Аналіз останніх досліджень і публікацій, у яких започатковано розв'язання проблеми. Незважаючи на короткий період дослідження передпосівної обробки насіння оптичним випроміненням, уже опубліковано достатньо значну кількість праць $[4,5,6,8,9,13,14,17,18]$.

Так, у [8] досліджувався вплив УФ-опромінення сухого насіння моркви на іiі зростання, морфогенез та рівень вмісту фітогормонів. Доведено, що опромінення насіння моркви УФ-С сприяє прискоренню росту наземної частини цих рослин у порівнянні з контрольними. Різниця в кінці вегетації становила $57 \%$. Опромінення
УФ-В також стимулює ріст наземної частини рослин, але в меншій мірі ніж УФ-С, а УФ-А практично не впливає на результат. Продуктивність рослин за передпосівного опромінення насіння також збільшилась - середня вага коренеплодів у разі опромінення УФ-С становила 85,4 г проти 68,8 г для контрольних рослин. Також показано, що передпосівна обробка УФ-С призвела до збільшення вмісту ауксинів і зменшення вмісту абсцизової кислоти. На основі цих досліджень зроблені висновки про вплив УФ радіації на динаміку листкового утворення, росту коренеплодів моркви, а також на вміст і активність фітогормонів.

У [9] досліджували вплив передпосівного УФопромінення на вміст фітогормонів в листках кінських бобів. Показано, що передпосівне УФопромінення насіння сприяє підвищенню адаптаційних властивостей рослин, які проростають в екстремальних умовах.

Великий інтерес викликає застосування УФопромінення для стимулювання зростання та підвищення стійкості рослин до зовнішніх чинників і збільшення врожайності сільськогосподарських культур.

Обробка передпосівного матеріалу бактерицидним УФ-випромінюванням в області $\mathrm{C}$ не тільки збільшує енергію проростання та схожість насіння [1, 6, 19,], а й знезаражує його [17].

Так, у роботі [6] відзначається позитивний вплив передпосівної обробки насіння УФ-випромінюванням: підвищується енергія проростання та польова схожість насіння, що забезпечує стійкі врожаї декоративних культур. У роботі [19] показано, що опромінення УФ-С насіння пшениці стимулювало його проростання. Авторами [1] проведені лабораторні дослідження схожості насіння пшениці після обробки ультрафіолетовим випромінюванням із різним спектральним складом. В якості джерела випромінювання використовували ксенонові лампи за наступних значеннях доз опромінення: 24, 48, 72, 96, 120 Дж/м². 


\section{СІЛЬСЬКЕ ГОСПОДАРСТВО. РОСЛИННИЦТВО}

Після обробки УФ-випромінюванням зростає енергія проростання і польова схожість насіння [1], а також підвищується врожайність [2, 4, 12, 16] і стресостійкість $[4,11]$, оскільки відбувається вплив на рівень пероксидази [10].

В Інституті лісу НАН Білорусі (м. Гомель) розроблена система передпосівної обробки УФвипромінюванням сільськогосподарського і лісового насіння. Стверджується, що передпосівна обробка насіння стимулює фізіологічну активність зародка, підвищуючи його енергію, i не спричиняє негативної дії на спадкову систему. В опроміненого насіння енергія проростання збільшується на 20-30 \%, схожість - на 15-25\% порівняно з неопроміненим.

У роботі [17] автори досліджували вплив бактерицидної дії УФ-випромінювання на інгібування парші клубнів картоплі. За УФопромінення дозами 10-15 кДж/м² інгібування розповсюдження хвороби знизилось на 25-28 \%, а ступінь розвитку - на 56-62\%.

Вплив УФ-випромінювання на картоплю було досліджено співробітниками Всеросійського науково-дослідного інституту сільськогосподарської радіології та агроекології (м. Обнінськ) в насінницькому картопляному господарстві ТОВ
«Клон-Агро» Жуковського району Калузької області [4]. Проводили УФ-опромінення клубнів картоплі різних сортів перед посадкою і закладанням на зимове зберігання. Результати польових випробувань УФ-установки i технології опромінення показали, що прибавка врожаю за всіма вивченими сортами (11 сортів) становила від 10 до $40 \%$. Також відбувається зниження зараження клубнів грибковими захворюваннями.

Мета досліджень - дослідити вплив ультрафіолетового (УФ) опромінення клубнів картоплі перед садінням на ії зростання та продуктивність у кліматичних умовах Полтавської області.

Завдання досліджень - встановити вплив передпосадкового УФ-опромінення на процеси розвитку і продуктивності картоплі.

Матеріали та умови досліджень. Нами проведені експериментальні дослідження впливу УФ-опромінення середньоранніх сортів картоплі «Утро ранее» та «Рокко» ультрафіолетовим випромінюванням діапазону С. При дослідженнях використовували ультрафіолетові ртутні розрядні лампи низького тиску $[3,15]$. Характеристики ламп представлені в таблиці 1.

Схема установки для передпосівного опромінення клубнів картоплі наведена на рисунку 1.

\section{1. Характеристики лампи з кварцового скла Jiangyin Feiyang Instrument Co., Ltd.}

\begin{tabular}{|c|c|c|c|c|}
\hline Тип лампи & $\begin{array}{c}\text { Потужність P, } \\
\text { Вт }\end{array}$ & $\begin{array}{c}\text { Струм I, } \\
\text { мA }\end{array}$ & $\begin{array}{c}\text { Напруга на лампі U, } \\
\text { В }\end{array}$ & $\begin{array}{c}\text { УФ-опроміненість } \\
\text { на відстані } \\
1 \text { м, Вт/см }\end{array}$ \\
\hline ZW23D15W(Y)-436 & 23 & 420 & $40-55$ & $62-69$ \\
\hline
\end{tabular}
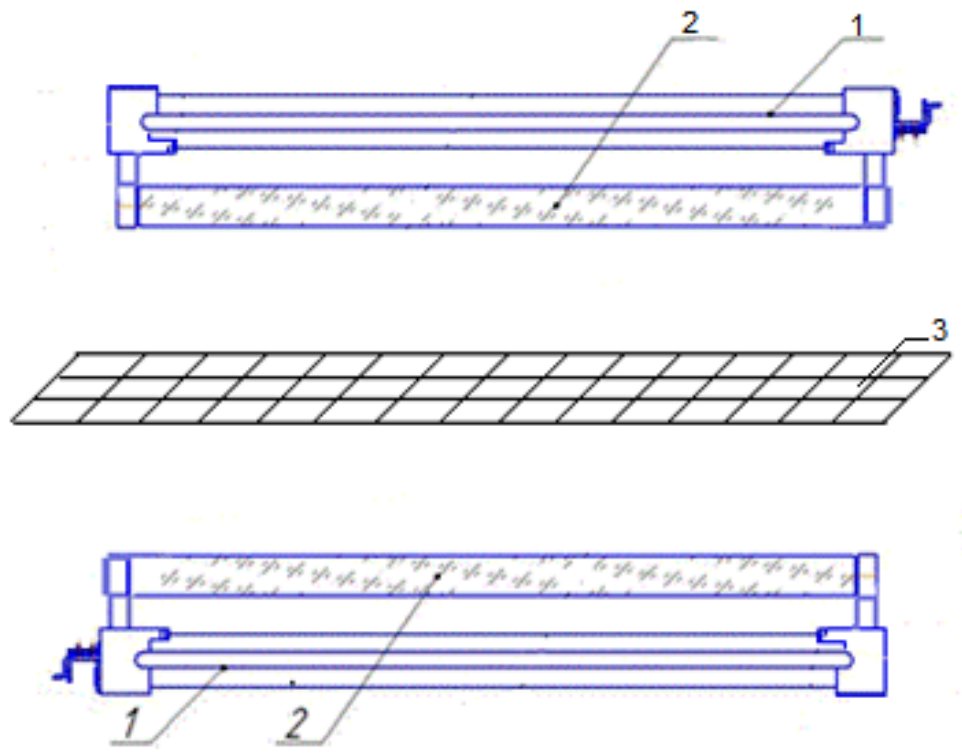

Рис. 1. Конструкція установки для УФ-опромінювання клубнів картоплі: 1 - корпус опромінювача; 2 - УФ лампа; 3 -решімка 


\section{СІЛЬСЬКЕ ГОСПОДАРСТВО. РОСЛИННИЦТВО}

Картопля в один шар укладається на решітку (3). Знизу і зверху на відстані 0,5 м встановлені УФ-опромінювачі. Часом опромінення та відстанню до УФ-джерел можна створити необхідну дозу опромінення.

Результати досліджень. Проведені експериментальні дослідження повинні були дати можливість перевірити відтворення результатів [4].

Експериментальними дослідженнями встановлено, що у рослин 3 опроміненими клубнями прискорено утворювалися і розвивалися первинні коріння. Відлік часу аналізу ефектів, що проявляються під дією УФР, було визначено 7 діб, оскільки у клубнів без будь-яких обробок первинні коріння починають з'являтися саме до цього періоду часу. В разі опромінення клубнів картоплі сорту «Утро ранее» дозою 120 Дж/м² (схема 1) середня довжина їх коренів була на $65 \%$ більше, ніж у контрольному варіанті, а в разі опромінення дозою 240 Дж/м² (схема 2) - на 82 \% (табл. 2). Подібна динаміка спостерігалася і у сорту «Рокко» (табл. 2).

Представлені експериментальні дані свідчать про те, що УФ-опромінення клубнів картоплі перед садінням сортів «Утро раннее» та «Рокко» дозами 120 і 240 Дж/м² стимулює процеси ризогенезу, що підтверджено отриманими результатами в роботі [7].

У випадку опромінення клубнів картоплі за схемою 2, тобто за поступового накопичення дози опромінення, помітних змін не зафіксовано в порівнянні 3 опроміненими клубнями за схемою 1. Відмінності контрольних і опромінених зразків по динаміці висоти рослин у вивчених сортів були різними (табл. 3,4 ).

Подальшими спостереженнями встановлено, що відмінності між контрольними рослинами та опроміненими ставали більш явними в процесі їх росту. Так, дані табл. 3, 4 свідчать про різницю в довжині рослин. Різниця між контрольними зразками і рослинами 3 опроміненими клубнями через 20 діб становила 27,3-29,0\%, а через 45 діб - 21,2-25,4 \%. Висота досліджених зразків за схемою 1 та схемою 2 в процесі росту залишалася однаковою, істотної зовнішньої різниці не виявлено (табл. 3, 4).

\section{2. Вилив дози ультрафіолетового випромінювання на процеси ризогенезу картоплі сортів «Утро раннее» та «Рокко»}

\begin{tabular}{|c|c|c|c|}
\hline \multirow{2}{*}{ Сорт картоплі } & \multirow{2}{*}{ 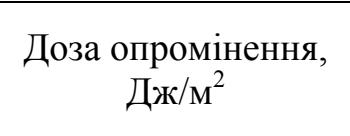 } & \multicolumn{2}{|c|}{$\begin{array}{c}\text { Середня довжина коренів, після опромінення, } \\
\text { мм }\end{array}$} \\
\hline & & 3 доби & 7 діб \\
\hline \multirow{3}{*}{ Утро раннее } & Контрольний зразок & 0 & $8,0 \pm 1,0$ \\
\hline & $120($ схема 1$)$ & 4 & $13,2 \pm 2,0$ \\
\hline & 240 (схема 2) & 6 & $14,6 \pm 2,0$ \\
\hline \multirow{3}{*}{ Рокко } & Контрольний зразок & 0 & $5,0 \pm 1,0$ \\
\hline & $120($ схема 1$)$ & 3 & $8,5 \pm 2,0$ \\
\hline & 240 (схема 2) & 4 & $9,3 \pm 2,0$ \\
\hline
\end{tabular}

3. Динаміка висоти рослин за передпосадкового УФ-опромінення клубнів картоплі сортів «Утро раннее»

\begin{tabular}{|c|c|c|}
\hline \multirow{2}{*}{ Зразки } & \multicolumn{2}{|c|}{ Кількість діб після опромінення } \\
\hline & 20 & 45 \\
\hline \multicolumn{3}{|c|}{ Висота рослин, мм } \\
\hline Контрольний & 75,0 & 172,1 \\
\hline Дослідний, 120 Дж/м² & 105,1 & 230,6 \\
\hline Дослідний, 240 Дж/м² & 106,4 & 229,7 \\
\hline
\end{tabular}

4. Динаміка висоти рослин за передпосадкового УФ-опромінення клубнів картоплі сортів «Рокко»

\begin{tabular}{|c|c|c|}
\hline \multirow{2}{*}{ Зразки } & \multicolumn{2}{|c|}{ Кількість діб після опромінення } \\
\hline & 20 & 45 \\
\hline \multicolumn{3}{|c|}{ Висота рослин, мм } \\
\hline Контрольний & 75,0 & 172,1 \\
\hline Дослідний, 120 Дж/м² & 103,2 & 215,6 \\
\hline Дослідний, 240 Дж/м² & 102,5 & 212,7 \\
\hline
\end{tabular}




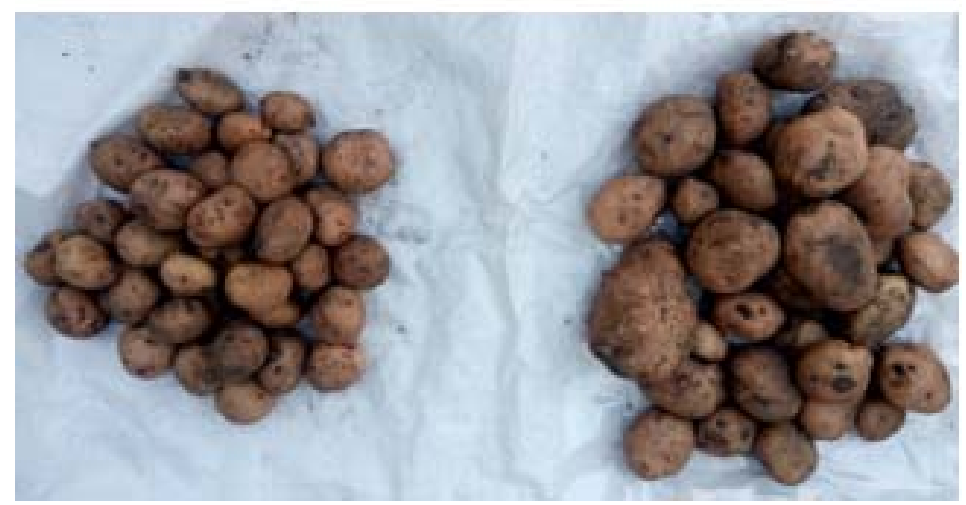

Рис. 2. Різниця в масі між контрольними зразками картоплі $і$ УФ-опроміненими (зліва - контрольний зразок, справа - УФ-опромінений)

Також слід зазначити, що вегетаційний період рослин 3 опроміненими клубнями картоплі пройшов на 12-14 днів раніше в порівнянні 3 контрольними зразками. Після збору врожаю середня маса клубнів картоплі була більшою в опромінених зразках в порівнянні з контрольним варіантом (рис. 2), при цьому їх кількість також була більшою. Це має суттєве значення в первинному насінництві картоплі. Збільшення врожаю в разі УФ-опромінення клубнів картоплі перед садінням становило в 2016 році $15 \%$, а в 2017 році - $12 \%$.

Отримані дані добре узгоджуються 3 даними [4], де зроблено висновки, що стимулююча дія УФ-променів супроводжувалася змінами швидкості асиміляції, вуглеводного і білкового обмінів рослин, що в подальшому вплинуло на збі-

\section{БІБЛІОГРАФІЯ}

1. Газалов В. С. Влияние режимов предпосевной обработки ультрафиолетовым излучением на схожесть озимой пшеницы / В. С. Газалов, Н. Е. Пономарева // Электротехнологии и электрооборудование в $\mathrm{c} / \mathrm{x}$ производстве. Зерноград, 2004. - Вып. 4. - Т. 1. - С. 46-49.

2. Газалов В.С. Эффективность источников инфракрасного излучения в предпосевной обработке семян / В. С. Газалов, Н. Е. Пономарева // Электротехнологии и электрооборудование в $\mathrm{c} / \mathrm{x}$ производстве. Зерноград, 2005. - Вып. 5. - Т. 1. C. $15-18$.

3. Дослідження та розробка вдосконалених конструкцій ультрафіолетових джерел випромінювання для установок фотохімічної і фотобіологічної дії : звіт про НДР (заключ.) : № 1 від 01 січня 2011 р. / ВНЗ Укоопспілки «Полтавський університет економіки і торгівлі» ; кер. Кожушко Г. М. ; виконав. : Семенов А. О. [та ін.]. Полтава, 2015. - 306 с. - № ДР 0112U007433. Інв. № 0715U003750. льшення врожаю.

Висновок. В рослинах, клубні яких перед садінням були опромінені дозою УФ-С 120-240 Дж/ $\mathrm{m}^{2}$, посилюється вегетативний ріст, збільшується врожайність, збільшується коефіцієнт розмноження. Цей ефект може знайти практичне використання під час вирощування картоплі без використання хімічних препаратів та стимуляторів росту. Крім того, даний метод можна використовувати для прискореного розмноження особливо цінних і нових сортів картоплі для первинного насінництва.

В подальшому планується провести дослідження передпосівного впливу УФ-опромінення на розвиток і продуктивність інших сільськогосподарських культур.

4. Зейналов А. А. От оборонных разработок к экологически чистым технологиям для сельского хозяйства [Електронний ресурс] / [А. А. Зейналов, А. Г. Ипатова, А. Н. Летова и др.] // Высокие технологии XXI века : 5-й Международный форум (Москва, 19-23 апреля 2004 г.), секция «Перспективы реализации высокотехнологических проектов в областях медицины и биотехнологии» Тезисы доклада. - Режим доступа : http:/www.hitechno.ru/?page=archive01 (дата звернення: 21.12.17). - Назва з екрана.

5. Караев М. К. Применение люминесцентного спектрального анализа для сортировки картофеля и влияние УФ облучения на сроки его хранения / М. К Караев, Х. М. Абдулаев, 3. А. Исаев, В. И. Савина // Сборник научных трудов Международной научно-практической «Инновационное развитие аграрной науки и образования» (23.12.2015). Махачкала. - 2016. T. 2. - C. $147-152$. 


\section{СІЛЬСЬКЕ ГОСПОДАРСТВО. РОСЛИННИЦТВО}

6. Кондратьева Н. П. УФ светодиодная облучательная установка для обработки семян перед посевом / Н. П. Кондратьева, М. Г. Краснолуцкая, Р. Г. Большин // Агротехника и энергообеспечение. - 2016. - №4 (13). - Т.1. - С. 22-31.

7. Кононенко А. Н. Влияние различных источников света на развитие мини-растений картофеля в условиях светокультуры / А. Н. Кононенко // Известия санкт-петербургского государственного аграрного университета. - 2016. - №45. C. $50-56$.

8. Одилбеков $K$. Влияние предпосевной обработки семян УФ-лучами разной длины волны на ростовые процессы, уровень гормонов и продуктивность растений / К. Одилбеков // Докл. Академии наук республ. Таджикистан. - 2007. T. 50. - № 2. - C. 165-171.

9. Одилбеков $К$. Влияние предпосевной обработки семян УФ-светом разной длины волн на активность комплекса фитогормонов в листьях конских бобов / К. Одилбеков // Докл. Академии наук республ. Таджикистан. - 2013. - Т. 56. №10. - С. 827-831.

10. Рогожин В. В. Влияние малых доз ультрафиолетового облучения семян на состояние антиоксидантной системы, прорастающих зерен пшеницы / В. В. Рогожин, Т. Т. Курилюк // Известия ТСХА, 1999. - №3. - С. 105-124.

11. Рогожин B. В. Влияние ультрафиолетового облучения семян на процессы перекисного окисления липидов в проростках пшеницы / В. В. Рогожин, Т. Т. Курилюк // Известия ТСХА, 1997. - №3. - C. 116-131.

12. Савельев В. А. Обработка семян пшеницы ультрафиолетовыми лучами / В. А. Савельев // Вестник с/х науки, 1990. - №3. - С. 133-135.
13. Сафаралихонов А. Б. Влияние предпосевного УФ-обучения семян растений пшеницы на их последующий рост и интенсивность транспирации листьев / А. Б. Сафаралихонов, Ф. Н. Худоербеков // Докл. Академии наук республ. Таджикистан. - 2016. - Т. 59. - №7-8. - С. 344-348.

14. Семенов А.О. Аналіз ролі УФвипромінювання на розвиток і продуктивність різних культур / А. О. Семенов, Т. В. Сахно, Г. М. Кожушко // Світлотехніка та електроенергетика. - 2017. - №2. - С. 3-16.

15. Семенов А. О. Безозонні бактерицидні лампи для установок фотохімічної і фотобіологічної дії / А. О. Семенов, Г. М. Кожушко, Л. В. Баля // Технологический аудит и резервы производства. - 2015. - №4/1 (24). - C. 4-7.

16. Серегина М. Г. Предпосевное облучение семян повышает урожайность / М. Г. Серегина // Кормопроизводство, 1984. - №4. - С. 27-28.

17. Тихонов А. В. Действие гамма, УФ- и СВЧ-облучения на клубни картофеля / А. В. Тихонов, В. Н. Тихонов, И. А. Иванов, Т. Ф. Еникеева // Современная техника и технологии. -2016. - №11. - Ч. 1. - Режим доступу : http: // technology.snauka.ru/2016/11/11072 (дата звернення : 15.12.2017). - Назва з екрана.

18. Jakubowski T. Impact of UV-C radiation on the infestation degree of the stored potato tubers with rhizoctonia solani kuhn / $\mathrm{T}$. Jakubowski, T. Pytlowski // Agricultural engineering. - 2015. - V. 2 (154). - P. 35-43.

19. Rupiasih N. Nyoman. Effect of UV-C radiation and hypergravity on germination, growth and content chlorophyll of wheat seedlings // AIP Conference Proceeding. - 2016. - V. 1719(1). P. 030035-030035.6. 